\title{
The horizons of the constitution: Politeia, the political regime and the good
}

\begin{abstract}
How do we think about the word politeia when this involves a reaching back to the past? The response, pursued in this paper, is that in the classical understanding of politeia there is a significant connection between the question of the 'good' and the constitution; a connection which has become occluded or obscured by modern constitutional thought. In support of this understanding of politeia it must be acknowledged that what is meant, in this paper, by 'good' is very different from that conventionally found in contemporary constitutional, legal or political theory. In an effort to disclose how politeia unravels this novel sense of 'the good' the paper will closely consider the philosophical work of Hans-Georg Gadamer on Plato. The paper claims that this largely neglected work is of importance to contemporary constitutional philosophy, particularly in so far as it focuses, as in this paper, on classical traditions or origins within constitutional thought.
\end{abstract}

\section{Constitutional Uncertainty}

This paper opens out the possibilities of meaning (the horizons) evoked by politeia by allowing it to become a philosophical problem for current constitutional thought. Taking this approach invites two initial questions: how does evoking politeia itself become a feasible possibility in the context of current constitutional debates, and why must this inquiry be considered a philosophical one.

In setting out a response to the first issue it is necessary to consider the uncertainty over the scope of the word constitution. Uncertainty can be a matter of linguistic practice, or may refer to the unclear abstract criteria for the types of phenomena brought within the word constitution; however, the kind of uncertainty referred to here brings with it the attribution of temporality. Initially, we might pursue the uncertainty of temporality as indicating a concern about the historical legacy of constitutional thought, in particular, whether there is any continued relevance in the pre-modern traditions of politics and constitutionalism, or alternatively, whether it is appropriate to fix what we mean by 'the constitution' as intrinsic to the emergence of political modernity. An illustration of this initial sense of temporal uncertainty can be found in the exchange between Giovanni Sartori and Graham Maddox.

In pursuit of a precise and clearly defined meaning of constitution, for scientific research in comparative politics, Sartori settled upon a teleological sense of constitution where the constitution was to guarantee rights to individuals by placing limits on governmental power. Outlining this definitional understanding of the constitution Sartori sought to distinguish between the modern demands of a more delimited sense of constitution compared with the more open-ended term for constitution which stems from the Latin word constitution, derived from the verb constituere (Maddox, 1982, p.805). In part, Sartori's qualms about the Roman constitutio stemmed from a sense that it was synonymous with lex and edictum - laws enacted by imperium or sovereign authority - the opposite of modern democratic constitutionalism. In 
response, Maddox suggests that Sartori overlooked the broader implications of the word constitutio which goes beyond a formalised enactment of law to encompass something wider. Recalling the words of Cicero in De Republica, Maddox suggests constitutio becomes the 'establishment of the state through the evolution of its institutions' (Maddox, 1982, p.806) - the founding [of Rome]. In other words, constitutio was not simply a question of the enactment of legally valid laws but encompassed a more expansive meaning concerning the foundation of the distinctive political experience of Rome. To this end Maddox suggests a connection between constitutio and an ancient Greek word, politeia:

'Cicero's use of constitutio refers to the mode in which a state is established and

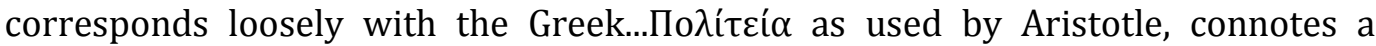
complete description of the forces operating within the polis to produce its public life, and as the Greeks scarcely distinguished between what was public and what was private, the constitution had to be resolved in terms of a description of the life of the city itself.....such a wide, imprecise notion was certainly the object of Sartori's attack.' (Maddox, p.806)

Hence, a preliminary response to the first issue is that the call to consider the term politeia is appropriate because there is an uncertainty about the scope of the term constitution which is temporal - which in a broad sense 'looks back' to earlier understandings or examples (premodern) in order to better understand the current possibilities open to constitutional theory. In turn this raises the second matter; namely, why does looking back to politeia imply a philosophical inquiry?

Returning to the exchange between Maddox and Sartori it might be asked; what is at stake in the alternative view of the historical legacy of the constitution presented by Maddox? To respond to this it must be understood that uncertainty over the historical scope of constitutional phenomena becomes ancillary to the concerns about application for current constitutional studies, particularly in response to question concerning the nexus between constitutionalism and the state. The term application is intended to refer to the way that constitutional theory has framed the historical scope of 'constitution' as a normative and epistemic problem of application. ${ }^{1}$ For instance, this is most apparent in the issues surrounding the relationship between constitutionalism and governance. In Europe, as well as other international practices and institutions, there is a lively debate as to whether the language and normative expectations created by the historical legacy which ties constitutionalism to the nation-state can find a place or whether the plural and multifaceted constellations of these new frames of governance and administration require, for the time being, to be thought of in their own terms (Loughlin and Dobner, 2010). In this way the use of 'global'; for example, in global administrative law; global law or global constitutionalism attests to the uncertainty over the application of 'constitution' to the new spatial sites of complex political, legal and economic governance. These theoretical anxieties, created by the problem of application, has lead to a further 'thinning' or 'narrowing' of the normative implications of 'constitution' to the procedural or administrative restraint on constituted public power in order to guarantee the protection of private rights and democratic

\footnotetext{
1 We can also suggest that the notion of application also includes the tendency of adapting modernist constitutional theory to the de-centred contemporary governance demands.
} 
governance or in some instances the call for 'constitution' to be jettisoned altogether in these discussions (Nico Krisch, 2010).

Making the question of application predominant in this way may respond to the current demands placed on constitutional theory; however, it is a strategy that also poses risks that alternate approaches and ways of thinking about such problems are marginalised and neglected. Accordingly, the implication of this study is that the temporal uncertainty of 'constitution' is converted into a criterion of normative or epistemic application or adaption which leads to neglect of the role that a philosophical account may play in placing temporality at the fore-front of our intrinsic understanding of the constitution.

Philosophy gains its initial traction by reflecting on the question: what has been occluded from our current sense 'constitution' which we can recover from the earlier politeia? In this paper, what has been occluded from politeia is the question of 'the good'. The problem of the good is explored here through the work of the hermeneutic philosopher Hans-Georg Gadamer on classical Greek thinkers, notably Plato. The careful interpretative work undertaken by Gadamer reveals how radically different classical writers understood the question of the good and its intimate relationship to politeia. However, re-appropriating the novelty of the good for today's constitutional thought might still remain within what has been termed application were it not possible also to understand the other significant philosophical dimension encountered in Gadamer (and also in the other philosopher considered in the paper, Claude Lefort) namely that hermeneutically meeting the 'past' may alter the horizon of understanding in the present where this horizon is not normative but rather an experience of our being in the world, in other words a 'horizon' of fundamental ontology. This becomes the philosophical challenge posed by the paper for an understanding of the 'constitution'.

Having set out the two core issues around which the analysis and approach of the paper is organised it is also worth introducing another point of interest. As already commented upon the paper considers the problem of politeia principally through the lens of 'the good' - and in doing so revitalises a reading of Gadamer's work on Plato. Additionally, the paper considers the relationship between politeia and the term 'political regime', used in political philosophy, and in doing so it became useful to consider the connections and dissonances between Gadamer and the French political thinker, Claude Lefort. The imagined dialogue between these two philosophers becomes a way of approaching the deeper tensions between the modernist constitutional project as regime and the classical sense of politeia thus indicating the critical landscape of possibility for constitutional thinking.

\section{Politeia and 'political regime' compared}

Generations have been influenced by classical ideas about politics, the constitution and political community from the early Christian neo-Platonists to liberal theories of politics. Given this influence, across a vast history, the focus will be on the more selective issue of pointing to the importance of making politeia a problem for the dimensions of contemporary constitutional thought, and in particular, the more recent understanding of it as political regime. To this extent the paper concentrates on two major (but very different) contributions to our understanding of 
political regime - Leo Strauss and Claude Lefort. The latter becomes significant as a point of 'dialogue' with Gadamer.

The classical problem of politeia becomes an issue for Leo Strauss because of the concerns he held regarding the vitality of political philosophy. Strauss laments that the state of political philosophy was in decline in part due to the separation of political science from political philosophy and the further parcelling off of the duties of the political philosopher to other disciplines such as economics and social psychology (Strauss, 1959). It is this sense of neglect of 'political things' that led to Strauss turning to classical political philosophy. In other words, Strauss looked to classical political philosophy as a source for the revivification of the task 'to understand the nature of political things' - a quest which Strauss sees as an essential practical exemplification of the need for political philosophy.

Critical to this strategy is to point out that what we understand as the political constitution in modernity has become unduly narrowed to the institutional coordination of governance and the recognition of private rights (in other words, precisely the sort of definition of 'constitution' favoured by Sartori). The strategy of looking back to politeia becomes one which seeks to appeal to a much wider understanding of the phenomena brought within 'the constitution':

Regime becomes the guiding theme of political thought when the derivative or questionable character of the laws has been realized.....Regime is the order, the form, which gives society its character. Regime is therefore a specific manner of life. Regime is the form of life living together, the manner of living of society.....'(Strauss, 1959, p.33-34)

The reference, in this passage, to the 'form of life living together' recalls the crucial orientating term for Plato, in various dialogues, ${ }^{2}$ of koinônia (communion) our being which is communal in the polis. How did Strauss see political philosophy as disclosing or aiding thinking about the form of life living together? The response by Strauss draws on one of the most fundamental pillars in the classical understanding of politeia: that of the good (agathon) and, implicitly thereby, justice (dikaiosynē):

Because of its direct relation to political life classical political philosophy was essentially 'practical' ....in contrast to [political science] political philosophy pursued practical aims and was guided by, and cultivated in, 'value judgements'....since political controversies are concerned with 'good things' and 'just things', classical political philosophy was naturally guided by considerations of 'goodness and 'justice'. (Strauss, 1959, p.88-89)

It is evident that Strauss interprets the issue of the good as 'value' when he describes political philosophy as mainly concerned with 'the question of the best regime' or 'value judgements' (Strauss, 1959, p34). As we shall pursue, in section three of the paper, the problem of the good and its connections to politeia may be more complicated than suggested by Strauss in so far as we must depart from a 'value' reading of the good. Nevertheless, Strauss underscores that if we

\footnotetext{
2 For example, Sophist, Timaeus, Menexenus as well as the non-dialogue works such as the Republic and The Laws
} 
are to look back to politeia in a way that meaningfully speaks to contemporary concerns then foremost in doing so must be to understand what is at stake in the question of the good. To further enhance the complexities involved in evoking a broader sense of the constitution as based around the political regime the paper now considers the work of Claude Lefort.

At root Claude Lefort's approach shares a common concern with Leo Strauss' about the fate of political philosophy or political thinking. In circumstances whereby scientific and sociological approaches to understanding political phenomena have dominated there has been a concealment of the significance of philosophical stances (Lefort, 1988a). Parallels between Lefort and Strauss can further be found in the way that Lefort looked to the classical notion politeia in order to indicate the fuller 'social' dimensions of a political regime to which recourse to political philosophy must be made:

'The fact that something like politics should have been circumscribed within social life at a given time has in itself a political meaning, and a meaning which is not particular but general. This even raises the question of the constitution of the social space, of the form of society, of the essence of what was once termed the city [politeia].' (Lefort, 1988a, p.11)

In pursuit of the different senses of 'political constitution' opened up by reflecting back to politieia Lefort was able to deploy the flexibility of the French language to make a critical distinction between la politique (politics ) and le politique (the political). Tracing this difference Lefort writes that la politique (politics) is concerned with the ontic; 'the field of competition between protagonists whose mode of action and programmes explicitly designate them as laying claim to the exercise of public authority' (Lefort, 1988b). As such la politique has become the epistemological as well as normative domain of political scientists, sociologists and political historians searching, inter alia, for the factual matrices, structural typologies, or transmission of actions or the role played by élites (Marchart, 2007, p.90-91). What becomes concealed by the concentration on la politique is the wider form giving, or symbolic dimension, of le politique (the political) and which is in part identified with the earlier understanding of politeia recast as the 'political regime'. It falls to political philosophy (la pensée du politique) to ensure that this concealment is rendered visible:

'The political is thus revealed, not in what we call political activity, but in the double movement whereby the mode of institution of society appears and is obscured....this observation is in itself an invitation to return to the question that once inspired political philosophy: what is the nature of difference between forms of society?' (Lefort, 1988a, p11)

Clearly, the distinction between le and la politique is not intended merely to be a description of different disciplinary approaches to encountering political phenomena but to indicate that it also demarcates a different comportment towards thinking. The political is foremost a designation of an ontological ${ }^{3}$ aspect and as such adds a new impetus to the call for la pensée du

\footnotetext{
3 The reference to ontology is implied to be 'fundamental' there are significant connections between the later works of Merleau-Ponty which had become increasingly influenced by Heidegger and the development of Lefort's own approach to the political question: for further discussion see, Bernard Flynn, The Philosophy of Claude Lefort (2005)
} 
politique. Leaving aside, for a moment, the 'dramaturgical' metaphor in Lefort's work, an indication of the ontological dimensions of le politique can be located in the evocation of 'world'. Lefort writes about the political 'governing the access to the world' (Lefort, 1988b, 222) and suggests that this can primarily be understood in the rupture of an empirical temporal and spatial political relationship: 'what philosophy discovers in religion is a mode of portraying or dramatizing the relations that human beings establish with something that goes beyond empirical time and space within which they establish relations with one another' (Lefort, 1988b, p.223). It is especially noteworthy that it is from the calling into question the conventional temporality (and so the horizons) of politics (la politique) that Lefort arrives at an 'ontological' turn in his account of the political. The references to 'world', 'temporality' and 'space' convey a connection (via Merleau-Ponty) with the 'activity of existence' (ek-sistence) as an understanding of Dasein's Being-in-the-World, developed in division one of Sein und Zeit (Heidegger, 1962). What Lefort emphasises is that politics, in the sense of the political, must be understood as a path to encounter this involvement with world and as such discloses the opening of Being in the relations between each other (Mit-Sein).

Up to this point we have explored the parallels between Strauss' earlier account of classical politics as 'regime' and the understanding of political regime as le politique in Lefort's work. However, we must address the considerable and critical divergence between the two political philosophers over the implications or stakes facing political philosophy. Lefort cannot follow Strauss in the claim that uncovering what is occluded by modern approaches to political philosophy leads us back to a classical account. With Lefort there is a fundamental rupture in our entire comportment to politics making the sort of 'recovery' posited by Strauss undesirable (Flynn, 2005, p. 156-157). Above all, it is the figure of Machiavelli that is indicated as the fulcrum between these different 'worlds' of the political (Lefort, 2012). The 'Machiavellian moment' is a response to the Erfahrung (experience) of the dissolution of the classical and neoclassical Christian worlds - in this sense Machiavelli is the transformation of the political.

The Machiavellian moment is principally characterised by two aspects of transformation which rupture the ancient Platonic-Aristotelian heritage of politeia. The first is that conflict characterises the modern political settlement; and the second is that power replaces the 'good' as the orientation of political rule. In Machiavelli an irreducible conflict emerges between ruling and oppression; the people and the rulers; but Lefort seeks to indicate that this is not simply an account of an historical political conflict (i.e. politics of renaissance Florence) but that this conflict becomes the ontological ground of the political (Marchart, 2007, 98). ${ }^{4}$ Whilst it is true that Aristotle in the Politics had discussed the political pathologies of conflict the elevation of this dialectical opposition in politics would have had the effect of causing men to lose sight of their own agathon and that of the politeia (Manent, 1995, p.13). If the Machiavellian moment calls for our attention to focus on the 'pathologies' of the political regime it does so because of a further fundamental difference - the replacement of the question of the good with the problem of power. It was with the blunt politics in fifteenth century Florence that according to Manent meant that 'the public good can only be brought about by the power of violence and fear' (Manent, 1995, p.15). This displacement of 'the good' by 'power' enabled firstly politics to

\footnotetext{
${ }^{4}$ Marchart argues that Machiavelli serves as the precursor for the various dialectic accounts of the political from Marx to Schmitt.
} 
emerge from its medieval theological shackles and become an autonomous field of human affairs (Flynn, 2005, p.20), and secondly, as Manent notes, 'the discrediting of the idea of the good, coincides with the elevation of the idea of the people' (Manent, 1995, p.16). We find that this already points towards a matter of some significance; namely, that by the Renaissance the question of the good had already become compromised by its long reception as the foundation for a Christian political theology and was ripe for replacing with popular sovereignty. However, drawing a radical distinction between modern and pre-modern understandings of the political, exposes Lefort to the charge that significant points of continuity have been downplayed or left underdeveloped. Jacques Rancière, for instance, contends that the beginning of politics can be understood as the basis of a radical kind of inequality between poor and rich: 'politics causes the poor to exist as an entity' (Rancière, 1998, p.11), a problem which is as much present in the Greek political philosophy as in Machiavelli and as an experience of modernity. In turn this must point towards possibilities of understanding that the 'Machiavellian moment' does not become an unsurpassable rupture between modern and pre-modern but rather enables a recasting of the relationship between politeia and 'the good' in the light of the experience of poltical modernity. This is a question I will return to consider more directly in the context of the discussion of Gadamer.

Lefort's account of the ontology of the modern political regime, based around power, becomes expressed in terms of dramaturgy. The notion that the political must be understood ontologically as a stage rests on the preconditions of the political regime being a symbolic acting out of power and conflict: 'the delineation of a specifically political activity has the effect of erecting a stage on which conflict is acted out for all to see (once citizenship is no longer reserved for a small number) and is represented as being necessary, irreducible and legitimate' (Lefort, 1988b, p.227). Underlying the stage metaphor, as indicating the ontological contours of the political in modernity, is the transformative power of the political regime; in other words, power becomes the capacity to re-stage or re-enact the political moment. Lefort explores this by playing on the French verb for 'to place' or 'to put', mettre, such that the symbolic transformation in the staging of the political is understood in terms of: mise-en-scène (staging); mise-en-forme (shaping) and mis-en-sens (giving meaning):

'[regime cannot] exist until they have been given a form (mise en forme). Giving them a form implies both giving them meaning (mise en sens) and staging them (mise en scene). They are given meaning in that the social space unfolds as a space intelligibly articulated in accordance with a specific mode of distinguishing the real and the imaginary, the true and the false, the just and the unjust, the permissible and the forbidden, the normal and the pathological' (Lefort, 1988a. p.11)

'the idea that what distinguishes one society from another is its regime - or to be more accurate - its shaping (mise en forme) of human co-existence has in one form or another, always been present, and it lies, so to speak, behind the theoretical constructs and philosophical thought which are tested against the transformation of the world' (Lefort, 1988b, p.223)

Bernard Flynn in his account of Lefort's work undertakes a discussion concerning the convergences and divergences between Gadamerian hermeneutics and the interpretation of political philosophy by Lefort. Flynn concludes that what seems to be the fulcrum of this 
difference is the role of dialogue: for Gadamer 'interpretation becomes dialogue, a fusion of horizons that overcome an initial resistance to understanding' whereas Lefort avoids 'any identification between interpretation and dialogue....the relationship of dialogue, that of "the two" reduces the role of the "third" - what Lefort calls, following Lacan, the symbolic order' (Flynn, 2005, p.72).

The distinction between the "the two" of the dialogue and the symbolic staging which lies as a "third" withdrawing from the dialogue carries with it issues of considerable importance which will need to be unpacked through a consideration of Gadamer's work. Unlike Flynn I do not see the divergence between Lefort and Gadamer as concentrated around the issue of dialogue; as in many respects this obscures the common (ontological) ground between the two thinkers. Instead, it seems arguable that the more telling difference lies in what this "third" component might be for Lefort and Gadamer. For Lefort, as Flynn suggests, what provides the ontological ground (world) for the interpretation of the political, and the indeed the entire momentum towards the transformation of the political regime, is its symbolic staging. Looking to Gadamer it is not that interpretation, as hermeneutics (dialogue), of the political excludes a 'third' rather that Gadamer seeks to understand how the question of the 'good' can also act as the ontological ground ${ }^{5}$ of the political. Through Gadamer we can explore whether returning to the question of 'the good' interrupts the staging of the political by revealing what is occluded in the modern form of the political regime, politeia, as understood in Lefort. In other words, it might be said that we return to the question asked by Leo Strauss about the relationship between political regime and 'the good' having passed through the ontological lens provided by Lefort. It is hoped that this 'imagined dialogue' between Lefort and Gadamer about politeia will reveal intimations regarding the critical paths open for current understandings of the constitution.

\section{The problem of the good}

At the outset it is appropriate to observe that to ask about the question of the good (agathon) and its relationship to politeia necessitates an appreciation of the significant difference with modern evocations of 'the good' which have in many cases been truncated to a moral schema. As Eric Heinze argues contemporary legal theory (largely Anglo-American) lumps ancient Greek philosophy (principally Aristotle and Plato) into the much later natural law tradition (Heinze, 2007, p.324). In the case of Plato the tendency to neglect serious examination the significance of his texts reflects a continuing mistaken understanding of the theory of Forms (eide) which tends to be presented as the assertion of transcendental entities beyond the world of sensory perception guiding our moral conception of justice and the good. ${ }^{6}$ This deep rooted neglect regarding the depth and complexity of Platonic theories about the good can be attributed to dominant theoretical positions, associated with Kelsen, Popper and Russell, which have adopted a largely dismissive approach to Plato and have made erroneous connections between Plato and

\footnotetext{
${ }^{5}$ Not to be confused with an idea of a metaphysical foundation.

${ }^{6}$ An illustration of this can be found in a quotation that Heinze takes from Kelsen, 'As to the idea of absolute Goodness, [Plato] even expressly states it lies beyond all rational knowledge'
} 
authoritarian political positions. ${ }^{7}$ The task adopted here is not so much to launch a critique of these various positions, which have been allowed to shape the legal and constitutional approach to Plato, but instead to reflect on what has been occluded from constitutional theory in the absence of a more considered engagement with Plato. The focus of this paper is Gadamer's hermeneutical reading of Plato and particularly his attempts to decouple Plato from the metaphysical tradition into which he is often placed.

Gadamer is a figure more widely known within literary, theology and philological studies where his approach to philosophical hermeneutics emphasised that the way to interpreting a text entails a 'dialogue' of understanding in which the background (traditions) of the interpreter are inevitably projected onto the encounter with the text. Far from advocating a dogmatic sense of tradition, Gadamer suggests that it is dynamic and the worlds of the interpreter and the text are transformed through encountering each other - a moment where 'horizons' 'meet' (Gadamer, 2006). However, Gadamer was also a philologist with a keen interest in classical texts, particularly of Plato (Jean Grondin, 2003, p.109). Indeed, the trajectory of his approach to hermeneutics emerges from the close study he undertook of Plato's dialectical method for his habilitation, Plato's Dialectical Ethics (Gadamer, 1997). In the course of his career not only do we encounter the enduring significance of Greek thought to the advancement of his philosophical position but it is possible to understand that it is from his concern with Greek thinkers that we are also able to discern more clearly the radical nature of the political and constitutional dimensions of his work. Gadamer does not provide straightforward definitions and often the position he articulates is spread over a number of different published writings which thus merits teasing out. In this sense the reader is required to reassemble his works as if in dialogue and, in accordance with this hermeneutic spirit, to move from particular contributions to the 'whole' of the work. A particularly vital point to understand is that at times words are used to imply the same or similar meanings - so for instance dialectic can also imply dialogue (Sawyne Barthold, 2010). This largely determined the way the paper approaches the good since it appears to be considered by Gadamer (particularly in relation to the political aspect) by reference to three distinct but related terms: methexis (engagement); chōrismos (separation) and finally logos (speech) which can also mean dialectic and dialogue. In the analysis that follows the paper interprets these three terms as central to the development of the connection between the good and politeia in Gadamer's work and in doing so the paper draws on the allegory of the cave from the Republic.

\section{a) Methexis}

Beginning the recovery of the Platonic texts takes place in unison with appreciating that Plato wrote much of his work as dialogues rather than as propositions. This most straight forward of observations is put to great effect by Gadamer in being able to cut away layers of neo-platonic scholarship that has encrusted itself on the texts from late antiquity onwards (Gadamer, 1999). It is the open-ended freedom of dialogue that enables Gadamer to encourage us to understand that the features of the Platonic landscape that we consider to be fixed and immovable might not be so. In this way Gadamer contends that the those passages in which Plato discusses the

\footnotetext{
${ }^{7}$ Heinze emphasises that these simplistic approaches to Plato say more about our twentieth century experiences of totalitarian regimes as opposed to finding anything authentic in Plato.
} 
'Ideas' or the 'Forms' and their appearance in matter (hyle) must be read in way that allows the freedom of dialogue to be maintained. Later dialogues, such as the Parmenides, indicate 'the terminology used for the relationship between idea and appearance [are] extremely free' (Gadamer, 1986, p.10) such that we should not be too quick to reach conclusions about the transcendence of the 'ideas' or the 'forms' and their immanence in matter. Referring to the Parmenides, and also Philebus, Gadamer remarks that Plato seems to single out the word methexis (participation or engagement) in order to articulate this notion of the 'free play' between the 'particular appearance' of the 'universal (ideas)':

Thus it remains possible for Plato to use the expression mimesis (imitation) together with the pair of concepts copy and paradigm, from the Phaedo until the Timaeus. Methexis, on the other hand, describes starting from the other side, the being of the pure relationship....In the Philebus it is even possible for Plato to formulate the ontological status of what participates as genesis eisousian (coming into being)' (Gadamer, 1986, p.12-13)

What is indicated is that the appearance of the good is not a question of imitation (mimesis) of the 'ideal' good - but rather that the 'good' is unearthed in methexis (participation) whose movement is characterised by coming into being - i.e. never fully revealed or disclosed. Gadamer is, of course, preparing the way to understand that the essence of the movement of participation in the good is the dialectic (we will consider the sense that methexis gives rise to dialectic later).

The transition from mimesis to methexis, which in turn parallels the shift from the transcendental sense of good to one which the good is always coming into being as an openended problem drawing us into involvement, allows Gadamer to put forward both a radical reinterpretation of the Platonic tradition whilst at the same time not to entirely repudiate its metaphysical legacy in the development of western thinking. This deliberately balanced approach to reading Plato nevertheless exposes Gadamer to two kinds of dangers. The first, is the suggestion that the concern to maintain bonne volonté in reading Plato supports rather than 'overcomes' this metaphysical legacy in Plato and as such risks condemning Gadamer to be a marginal figure in the trajectory of post-Heideggerian philosophy. ${ }^{8}$ Secondly, Gadamer's philosophy is taken as a basis for a modified form of transcendental philosophy which places the 'good' as 'beyond being'. ${ }^{9}$ These varying ways that Gadamer is received indicates more readily the fractured nature of current directions in philosophy, particularly in so far they address the legacy of the classical tradition. However, the greater risk is that the novelty of Gadamer's reading of Plato becomes overshadowed by the wider uncertainties within the

\footnotetext{
${ }^{8}$ Such a 'balance' clearly enables us to appreciate the distinction that emerged between the Gadamerian approach to the legacy of Heidegger and 'Destruktion' the approach of Derrida as deconstruction. There is, of course, much literature exploring this point. In addition to the infamous meeting in Paris between Derrida and Gadamer published with commentary in Dialogue and Deconstruction: The Gadamer-Derrida Encounter ed. Diane Michelfelder and Richard Palmer (1989) also a useful additional commentary on this encounter and the implications of it, Dominique Janicaud, "Articulations/Disarticulations" in Phenomenology Wide Open (2005).

${ }^{9}$ For instance, Lauren Sawyne Barthold, Gadamer's dialectical hermeneutics, maintains a transcendental reading of Gadamer: 'the philosophical life and the pursuit of the idea of the good have in common that both are always on the way to something beyond human existence', xxi.
} 
current philosophical debates; with the knock-on effect that the implications of his work for composite fields and disciplines, such as constitutional theory, becomes secondary or assimilated into other positions such 'idealism' or 'communicative rationality'.

Turning to the well-known allegory of political education in Republic VII, about the cave dwellers, methexis provides an interesting interpretive lens with which to consider this passage. It points out two critical moments of drama and leaves them as open-ended problems about the consequences of education. Following the encounter with 'sun light' outside the cave the narrative abruptly returns to cave interior: 'Consider this too. If a man went down into the cave again and sat down in his same seat, wouldn't his eyes - coming suddenly out of the sun like that - be filled with darkness?' (Republic, p.516e) The shift from the exterior light back to the interior darkness raises the question: how will the returning cave-dweller adjust again; will he confront the others? In other words, the drama is not so much the access to what is beyond the cave but the survival of this truth once back inside the cave and so the fulcrum of the allegory is the movement towards an inevitable engagement over the 'good' which has been experienced. Further the 'allegory' suggests that this engagement is fraught with considerable risks and calls for tact: 'And if they can get hold of this person who takes it in hand to free them from their chains and lead them out, and if they could kill him, will they not actually kill him' (Republic, p.517). Methexis is inevitable once the good is learnt but that in turn calls for a particular kind of methexis with the cave dweller community which the protagonist is inescapably a part. What is also disclosed, it seems to me, is that what ultimately makes this kind of methexis possible is not whether the exterior light is a 'good' in a transcendental sense ${ }^{10}$ but that it can be experienced in two separate but connected worlds - what is most remarkable is the possibility that the good can be both inside and outside the cave and it is this that protagonist cave dweller understands. So this facet of the good as separate but also the self-same ${ }^{11}$ gives it a unique meaning and the word for this is chōrismos.

\section{(b) Chōrismos}

The significance that Gadamer accords to chōrismos must be understood alongside his placing of Plato's philosophy in the wider context of ancient Greek thought, in particular, that of the preSocratics. It is well-known that Gadamer's teacher, Martin Heidegger, approached the preSocratics, notably Heraclitus, as holding the possibility of a new beginning by returning to primordial thinking (Mattéi, 1995). Whilst Gadamer shared the view that thinking can be liberated from the frame of modernity he was also concerned to emphasise (ever mindful of tradition) the continuities between the pre-Socratics and the more systematised form of thinking which emerged in Plato. Gadamer claimed that there was an ambivalent picture of Heraclitus in the dialogues but this fundamentally alters with the Sophist when Plato decisively takes up the chörismos theme from Heraclitus and in doing so radically alters it:

But the Ionian muses thought it cleverer to weave the one and the many together by the Ionian muses he [Plato] undoubtedly means Heraclitus....What is attributed

\footnotetext{
${ }^{10}$ As has already been remarked this association between Plato and 'natural law' has tended to blight any serious and close examination of the significance of the writings for contemporary legal theory.

${ }^{11}$ This can be referred to in different ways as the 'one' and the 'many' or the 'unity' and 'multiplicity'.
} 
to Heraclitus here is the idea that the one and the many are the whole truth of being, not alternatively but in one. In reference to this, Plato has the stranger from Elea quote a statement from Heraclitus: the one that places itself apart from itself joins itself together with itself. (Gadamer, 2001, p.37-38).

In this passage we can understand that the movement of 'coming into being' by our engagement in the 'good', referred to in the earlier section, is a dynamic one premised upon a chörismos (separation) between the 'one and many' which nevertheless derives from the same 'form', or the self-same, or as Gadamer succinctly puts it, the being one of what is different. We can say that we are drawn to engagement (methexis) because we are appropriated (Ereignis) by the flux or movement between the 'one' and the 'many'; or the 'good' and its 'appearance'. The Heraclitan fragments, according to Gadamer, indicate this tense and often unstable sudden change between 'one' and 'many' which is symbolised by the reference to 'fire' and 'lightening':

'the fundamental experience of thinking here seems to be the essential unreliability of everything that seems to show itself sometimes in this way and sometimes in another. In the very next moment it can be different again and no longer present in another way' (Gadamer, 2001, p.39).

Drawing connections between Plato and Heraclitus over the philosophical beginnings of chōrismos Gadamer is able to articulate points of significance regarding how to understand both thinkers. For Plato there is the argument that the true origins of the dialectic and the question over the good are to be found in pre-Socratic thinking which means that there is a significant 'pre-metaphysical' element to be brought out. This fundamentally alters the way we approach the criticisms made by Aristotle of the chörismos between the 'Ideas' and appearance in matter since we have to take into account, according to Gadamer, the 'radical' way that Plato reconsidered questions of the good and chōrismos (after Sophist) in terms of the question of Being - as the being one of what is different (Gadamer, 1994, p.84). In respect of Heraclitus the association made with Plato emphasises that the seemingly prophetic fragments, particularly, concerning fire, logos and the 'one' ought not to be thought of as a cosmology. For Gadamer the fragments are the speculative beginnings of a philosophy of dialectic which would find its maturity in Plato. Thus, Heraclitus' 'one' was not a cosmological 'absolute' but rather an openended sense of 'the good' (the coming into being of the good). Indeed, Gadamer asks whether we can say that Heraclitus constructed a cosmology at all (Gadmer, 2001, p.42-43). Referring to the words of a later Stoic writer, by the name of Diodotus, Gadamer suggests that Heraclitus did not deal with physis (nature) but rather with the politeia and that the fragments might be said to be political in their dimension, 'we must ask ourselves [as a consequence] whether Heraclitus was a rival of the Ionian cosmologists at all and not more likely one of their critics'. It is significant, in Gadamer's reading, that the early thinking about politeia and the good begins as opposition to the cosmologists; a further indication that the good is an involvement which is at hand and unavoidable, rather than other-worldly and mystical.

The chorismos found in Heraclitus emphasises not only the being one of what is different but also that this entails a movement between the 'one' and 'difference' which is abrupt or sudden; such that the methexis in the good can be something in 'flux' or even 'fleeting' - it can 'bowl us over' without warning. The reason for the abruptness is that flux is harboured within the thing itself or the 'difference' is in the 'one'; as Gadamer writes, 
'He [Heraclitus] discerns this in such diverse phenomena as the flow of things, the abrupt change from fire into water and from sleeping into waking and he discovers the riddle in everything - in the flame that consumes itself and is extinguished, the motion that begins by itself and ceases by itself. Everywhere he sees the wonder of life, the riddle of being conscious and the mystery of death' (Gadamer, 2001, p.49).

The references to the chorismos as the flow of things between sleeping and waking, mirroring that between death and life, holds a particular captivation for Gadamer and reflects his sense that what Greek culture (including its politics) reveals is that insight comes from suffering (pathei mathos) and that the concrete experience of this suffering is one of finitude (Gadamer, 2004, p.351). Clearly, at the forefront of our thinking here would be the dramatic works of the Athenian golden age such as the tragedies of Sophocles, Aeschylus or Euripides which explore the chörismos and pathei mathos in a vivid way. Nevertheless, it is no less significant in the development of Platonic philosophy; for instance, recalling the 'cave allegory' in the Republic the transitions between inside/outside the cave are sudden and abrupt - there is no discussion of a choice, intention or will on the part of the cave dweller - and equally the movement between worlds ('transitionless otherness') is marked by the suffering associated with the experience of disorientation and temporary loss of sight.

Through the Heraclitus fragments, the question of the good as it involves chorismos is something that in a basic sense draws us into it; we cannot be passive or stand back from the good - this kind of methexis arising from the chōrismos is conveyed by Gadamer in a physical or bodily way as - touching (haptesthai):

'The spatial term for such a transitionless otherness is touching together (haptesthai) - the key word in the profound fragment 26 'The human being kindles a light in the night, when the eyes are extinguished. Alive, he touches the dead, awake he touches the sleeping' (Gadamer, 2001, p.74).

The good touches us. It is noteworthy that this quotation reveals striking parallels with the work of another great twentieth century post-Heideggarian philosopher, the French thinker Maurice Merleau-Ponty. In Merleau-Ponty's incomplete last work The Visible and the Invisible (1968) he develops an idea of the 'flesh', which resembles the place of the 'one' which features in Heraclitus, and also the 'touching reversibility' becomes similar to by the haptesthai and or Ereignis in Heidegger. Looking to the similarities between Gadamer and Merleau-Ponty it is suggestive that as Merleau-Ponty moves from his earlier position which is heavily influenced by Husserlian phenomenology to an ontological position informed by Heidegger and it is possible to encounter indirect references to the Platonic and pre-Socratic beginnings of philosophy. Although, a fuller account of the relationship between Gadamer and Merleau-Ponty and the preSocratics is indeed merited it falls outside the immediate scope of this paper. However, the issue raised here is that the connections between Gadamer and Lefort, who was influenced by Merleau-Ponty, run deep and point towards understanding the legacy of the beginnings of philosophy and the considerable influence it has on the questions of politics.

The radical understanding of chörismos is not confined to locating continuities between the preSocratics and Plato there is also the forward-looking link pursued by Gadamer which posed equally significant questions for the good. Although, as remarked earlier, Aristotle is cited as a 
critic of the Platonic 'forms', and the early understanding of the chörismos, as unbridgeable separation, Gadamer's work may be understood as implying significant connections between the radically altered sense of the chōrismos in Plato and Aristotelian ethics. Swayne-Berthold considers that the development of the good in terms chörismos enables Gadamer to claim important similarities with the dialectic chörismos between a distanced knowing (technē) and embedded knowing (phronēsis) both of which form part of the dynamic movement of knowing (Swayne Berthold, 2010, p.25). Understanding the question of the good in terms of situational judgement of phronēsis recalls not only the touched suffering of pathei mathos but furthermore returns to the ethical moment in the 'cave allegory', where the cave-dweller cannot 'stand-back' in his understanding of the good as it is both inside and outside the cave - thereby confronted by being in the embedded situation of the other cave-dwellers. However, at the same time the possibility of this situational response only comes about due to the distanced knowing from leaving the cave.

In turn, this raises the question as to what is it to confront the good in this situation? The response is logos which Gadamer develops as connected to the dialectic in Plato - we are invited to imagine that faced with the circumstances of his understanding of the good and of being back in the cave - our cave dweller will begin to speak and to enter into dialogue with the fellow cave-dwellers.

\section{(c) Logos}

Confronting the understanding that the question of the good is bound up with the ontological implications of the chōrismos as the being one of what is different enables us to understand that the resulting concerns about logos and dialectic in Plato acquire a political character. As Gadamer acknowledges, 'the question about the good and, in particular, about the good in the sense of arête [virtue], the bestness of the citizen of the polis dominates Plato's writings from the very start' (Gadamer, 1986, p.21). What Gadamer emphasised about the question of the good in the politeia is that it concentrates into the dilemma over the conduct of dialogue. In particular; the platonic dialogues revolve around the question: how do we know when our political discussions are guided by 'the good'?

The relationship between dialogue and 'the good' characterises what we might call the political and constitutional implications in Gadamer's hermeneutic philosophy. In the foregoing account of methexis and chōrismos it is emphasised that Gadamer understood Plato's works holistically and furthermore appreciated that it is possible, following the significant contributions to ontology by Heidegger, to realise that Plato intended for logos to be understood in terms of Being - a bringing into language of the chorismos of the being one that is different. In this way, rather than understanding political dialogue as being subject to a technical criterion of rational communication Gadamer recognises that what binds phronessis and the dialectic is a concern for the situational wisdom of conversation; a wisdom that only comes into view once the question of the good and its relationship to the ontological dimensions of the chorrismos are acknowledged. However, it would be an error to suggest that the distinction between conversation and communication could itself be the subject of some clear criterion; naturally it is not so straight forward and indeed a similar concern can be found in Plato. In the discussion of the Lysis Gadamer poses the problem in this way: 
'The difference between Socrates and the sophists is in no way an obvious one; rather it is a difference evident only to someone who has not only the logos in view but also the ergon' (Gadamer, 1980, p.5).

Ergon can be understood as deed; although as Gadamer develops this it is clear it conveys the sense of how someone comes to the conversation - the comportment in dialogue. This falls to our own judgement as not only how to recognise a conversation which turns away from a proper comportment and how to respond to this. The Platonic dialogues are replete with examples of the sophists' abandonment of dialogue which is accompanied by words which convey the kinds of distortion encountered: hedone (need or desire); phthonos (concern to be ahead or not be left behind); pseudo (concealment or falseness)(Gadamer, 1994, p.91-92). These words, and others, are intended to be contrasted with the care and attentiveness of friendship in dialogue

\section{A basis for a dialogue between Lefort and Gadamer?}

It is surprising, particularly in light of the themes in this paper, that one of the more prominent works written by Gadamer which contains implications for political thinking is one which ostensibly concerns the Greek festivals and the notion of art. Nevertheless, it is in The Relevance of the Beautiful (Gadamer, 1996) that it is possible to conceive what might be the elements which demarcate the classical politeia under the question of good from the modern sense of 'regime'. To explore this as well as understand the divergent, and convergent, contributions of Gadamer and Lefort the paper will focus on two related words used by both thinkers: the first is the symbol and the second the stage (Lefort) or festival (Gadamer) - the analogy between the ontology of the political and drama.

As developed in section 2 of the paper the symbol in Lefort emerges from the 'Machiavellian moment' where it might be said that 'power' and 'conflict' eclipses the question of 'the good' when determining the ontological character of the 'political regime'. It is a moment which is fraught with possibility and risk: on the one hand the opening space for popular sovereignty, but on the other, the embodiment of power in totality (Flynn, 2005, p.240). As Warren Breckman writes the symbolic dimension in Lefort's work performs an important role in seeking to 'check' the embodiment of power: 'power involves a symbolic representation of society that is not anchored in the real...the symbolic thus remains exterior or non-identical to the social' (Breckman, 2012, p32). That in addition to the factual exercise of power there should be a symbolic power constitutive of the regime which should be left in an 'empty place' or 'the power of nobody' becomes vital if democracy is to be safeguarded:

'I think it is really important to understand these two things in order to understand what democracy is: on the one hand, the people are heterogeneous, multiple, in conflict, and on the other hand there is power, which is the power of nobody' (Rosanvallon, 2012, p.10).

In Gadamer's account the symbol is free from confining power and instead becomes a window through which we encounter the temporal being of a community; it illuminates the horizon of an 'open future and an unrepeatable past' (Gadamer, 1996, p.10). The symbol takes on the token 
of remembrance; in the ancient Greek world in the way that a host presents to his guest a gift, tessera hospitalis, which he would break in two; one half would be kept by the host and the other given to the guest. If the guest should return then the two pieces would be joined together in an act of recognition (Gadamer, 1996, p.30). The symbol then becomes the fragments of memory or remembrance through which we can recognise a symbolic unity which can never actually be realised. Understood in this way it might be suggested that this classical sense of symbol also reveals the impossibility of a totality of the 'one': because in order to recognise the good we must also acknowledge chörismos as the movement of the being one of what is different. The tessera hospitalis becomes, then, the perfect symbol for the chörismos.

Turning to the centrality of the dramaturgical analogy in Lefort's work; in order to retain the 'empty place' of power in the political regime it must be symbolically staged and in the earlier sections the staging (mettre) of power was explored. Additionally, it is understood that the dramaturgical analogy was intended to explore the ontological dimensions of the political regime. In the essay The Relevance of the Beautiful Gadamer also develops a dramaturgical analogy of sorts to understand the temporal being of the politeia- he makes the comparison not with staging but with a festival: 'a festival is an experience of the community and represents community in its most perfect form' (Gadamer, 1996, p.39). What is it that the festival 'represents' of community for Gadamer? The festival celebration is a gathering of the community, '[it] is clearly distinguished by the fact that here we are not primarily separated but rather are gathered together' (Gadamer, 1996, p.40) Furthermore, the festival gestures towards the fulfilment of time - in contrast to empty time that needs to be organised, mapped or measured into a series of moments; the festival becomes filled with the experience of the celebration - in other words, temporality becomes coterminous with the lived experience of the festival such that it ceases to require calculation.

\section{Concluding remarks}

Central to the approach of this paper has been to argue that looking back to pre-modern traditions of thought about political and constitutional form can provide a critical perspective with which to look at current issues encountered by constitutional theory. This older tradition of linking politeia to 'the good' culminates in a different sense of collectiveness as the basis for political community. Admittedly this distinction seems somewhat abstract and in these concluding remarks the paper looks to provide an indication as to how these insights might shape research in constitutional theory.

A significant issue to which the concerns raised in this paper speak directly is how fundamental constitutional change is understood. In areas of legal and constitutional study which focus on significant and sudden change within a constitutional community there is often the search for a much wider sense of the term 'constitution' which can be capable of supporting the way that fundamental constitutional change is more than a series of alterations to the legal or political institutional matrix of that community. In the emerging field of transitional justice, for example, use is made of term politieia to indicate the broader range of issues that can be brought under the purview of constitutional justice (Teitel, 2000) as part of bringing about durable transition. In this paper examining the word politeia was intended not so much to revive a handy term or 
concept so as to make relevant a broader range of practices for constitutional theory rather it was to make politeia itself an aspect of philosophical questioning in order to indicate constitutional experiences occluded in contemporary constitutional thinking. The result is to expand the language, understanding and traditions that constitutional theory can draw upon when thinking about key current problems. Returning to the issue of fundamental constitutional change the research presented here touches upon significant thematic questions: the interconnections between politeia and 'the good' draws upon complex questions about change and difference (chörismos); the distinctive sort of involvement/participation (methexis) that reflection about chorismos engenders and the characteristic part that memory and remembrance play in understanding community bound together by questioning 'the good'. These reflections may provide at least new paths for constitutional thinking so as to enable a contribution to be made to areas such as transitional justice.

These observations inevitably return to the issue of application, raised at the very outset of the paper. It was argued that contemporary constitutional theory primarily approaches the question of theoretical uncertainty from the perspective as to how to adapt or apply the normative and epistemological claims that have emerged in the state (modernist) constitutional tradition to emerging constitutional practices beyond the state and in various global legal and political spheres. Consequently, there is a tendency to concentrate on what this paper terms the temporal uncertainty of the 'constitution' by focusing principally on the relationship between constitutional theory and the state form. In itself the paper does not take issue with this approach directly; however, the propensity to associate the issue of application so closely to the state form may in turn lead to truncating the possibilities for exploring pre-modern traditions in constitutionalism. Such a concern is not necessarily a narrow matter or a point of finer detail since underlying the approach of this paper is an effort to explore what 'applied constitutional theory' can entail by pursuing an historical and ontological approach (temporality). To this extent the paper has sought to argue for a philosophically rigorous and imaginative method to the kinds of questions and sources that can be explored by reflecting on the beginnings of the word 'constitution'. Consequently, application should also be taken to encompass a much broader range of issues from understanding the idea of 'constitutional change' to exploring how constitutional justice can be reflected upon in relation to 'memory' or 'past' of a community.

\section{Reference List}

Breckman,Warren. 2012. “Lefort and the Symbolic Dimension” 19:1 Constellations 32.

Flynn, Bernard. 2005. The Philosophy of Claude Lefort, Evanston: Northwestern University Press.

Gadamer, Hans-Georg. 1980. "Logos and Ergon in Plato's Lysis" in Dialogue and Dialectic, trans. Christopher Smith, New Haven: Yale University Press.

Gadamer, Hans-Georg. 1986. 'The Question at Issue' in The Idea of the Good in PlatonicAristotelian Philosophy, trans. Christopher Smith, New Haven: Yale University Press.

Gadamer, Hans-Georg. 1994. "Plato" in Heidegger's Ways, trans. John Stanley, Albany: State University of New York Press. 
Gadamer, Hans-Georg. 1996. The Relevance of the Beautiful, ed. Robert Bernasconi, Cambridge: Cambridge University Press.

Gadamer, Hans-Georg. 1997. Plato's Dialectical Ethics: Phenomenological Interpretations relating to the Philebus, trans. Robert Wallace, New Haven: Yale University Press.

Gadamer, Hans-Georg. 1999. "Thinking as Redemption: Plotinus between Plato and Augustine" in Hermeneutics, Religion and Ethics, trans. Joel Weinsheimer, New Haven: Yale University Press.

Gadamer, Hans-Georg. 2001. "Heraclitus Studies" in The Beginning of Knowledge, trans. Rod Coltman, New York: Continuum Press.

Gadamer, Hans-Georg. 2006. Truth and Method trans. Joel Weinsheimer, London: Continuum Press.

Grondin, Jean. 2003. Hans-Georg Gadamer: A Biography trans. Joel Weinsheimer, New Haven: Yale University Press.

Heidegger, Martin. 1962. Being and Time, trans. J.Macquarrie and E. Robinson, New York: Blackwells.

Heidegger, Martin. 1998. "Plato's Doctrine of Truth" in Pathmarks ed. William McNeill Cambridge: Cambridge University Press.

Heinze, Eric. 2007. 'The Status of Classical Natural Law: Plato and the Parochialism of Modern Theory' 20 Canadian Journal of Law and Jurisprudence 324.

Janicaud, Dominique, 2005. "Articulations/Disarticulations" in Phenomenology Wide Open trans. Charles Cabral, New York: Fordham University Press.

Krisch, Nico. 2010. Beyond Constitutionalism: The pluralist structure of postnational law, New York: Oxford University Press.

Lefort, Claude. 1988a. "The Question of Democracy" in Democracy and Political Theory, trans. David Macey, Oxford: Polity Press.

Lefort, Claude. 1988b. "Permanence of the Theologico-Political?" in Democracy and Political Theory, trans. David Macey, Oxford: Polity Press.

Lefort, Claude. 2012. Machiavelli in the Making, trans. Michael Smith, Evanston: Northwestern University Press.

Loughlin, Martin and Petra Dobner. 2010. The Twilight of Constitutionalism, New York: Oxford University Press.

Maddox, Graham.1982. "A note on the meaning of 'constitution'” 76 The American Political Science Review, 805.

Manent, Pierre. 1995. Intellectual History of Liberalism, trans. Rebecca Balinski, Princeton: Princeton University Press. 
Marchart, Oliver. 2007. Post-Foundational Political Thought, Edinburgh: Edinburgh University Press.

Mattéi, Jean-François. 1995. "The Heideggarian Chiasmus” in Heidegger from Metaphysics to Thought, trans. Micheal Gendre, Albany: State University of New York Press.

Merleau-Ponty, Maurice. 1968. The Visible and the Invisible, trans. Alphonso Lingis, Evanston: Northwestern University Press.

Michelfelder, Diane and Richard Palmer. 1989. Dialogue and Deconstruction: The GadamerDerrida Encounter, Albany: State University of New York Press.

Plato: Complete Works. 1997. Edited by John M. Cooper, Hackett Publishing, Cambridge Rosanvallon, Pierre. 2012. "The test of the Political: A Conversation with Claude Lefort" 19:1 Constellations 10.

Strauss, Leo. 1959. "What is Political Philosophy?" in What is Political Philosophy and other studies, Westport: Greenwood Press.

Swayne-Barthold, Lauren. 2010. Gadamer's Dialectical Hermeneutics, Lenham: Lexington Books. Teitel, Ruti. 2000. Transitional Justice, Oxford: Oxford University Press. 